\title{
Cadmium Contamination in Farmland Soil and Water Near Zine Mining Site
}

\author{
Pencemaran Kadmium pada Air dan Tanah Pertanian Dekat Lokasi \\ Pertambangan Zink
}

\author{
Kanitta Jiraungkoorskul*, Sara Arphorn*, Mathuros Tipayamongholgul**, Wattasit Siriwong***
}

\begin{abstract}
*Department of Occupational Health and Safety, Faculty of Public Health, Mahidol University, Bangkok, Thailand, **Epidemiology Department, Faculty of Public Health, Mahidol University, Bangkok, Thailand, ****College of Public Health Sciences, Chulalongkorn University, Bangkok, Thailand
\end{abstract}

DOI: http://dx.doi.org/10.21109/kesmas.v10i3.945

\begin{abstract}
This study was a cross-sectional study conducted in Phatadpadaeng Subdistrict, Mae Sod District, Tak Province, Thailand. This study aimed to determine cadmium concentration in farmland soil and water as well as at the residence of farmers and households. As many as 48 samples of farmers' residence soil and water, twelve samples of households and six samples of farmland soil and eight samples of farmland water were investigated for cadmium concentration using Graphite Furnace Atomic Absorption Spectrophotometer. The Mann-Whitney $U$ test was used for the analysis of the difference of cadmium concentration between farmland soil and residence soil, farmland water and residence water. The results showed no statistically difference among all matrixes, however, farmland soil and farmland water showed highest concentration compared to those of resident farmers and households. The cadmium concentrations in all samples were far below the limit values. This study clearly showed that working conditions of farmers demonstrated higher level of cadmium compared to the living conditions. The cause of this contamination might be from the activities of the surroundings industry. Therefore, it would be recommended that farmers should consider for cadmium exposure while working in farm.

Keywords: Cadmium concentration, farmland soil, farmland water
\end{abstract}

\footnotetext{
Abstrak

Penelitian ini merupakan penelitian potong lintang yang dilakukan di Kecamatan Phatadpaeng, Kota Mae Sod, Provinsi Tak, Thailand. Penelitian ini bertujuan untuk mengetahui konsentrasi kadmium pada air dan tanah pertanian serta pada pemukiman petani dan rumah tangga. Konsentrasi kadmium pada 48 sampel tanah dan air pemukiman petani, 12 sampel rumah tangga, enam sampel tanah pertanian, dan delapan sampel air pertanian ditelusuri menggunakan Graphite Furnace Atomic Absorption Spectrophotometer. Uji Mann-Whitney U digunakan untuk analisis perbe-
}

daan konsentrasi kadmium antara tanah pertanian dan tanah pemukiman, air pertanian dan air pemukiman. Hasil penelitian menunjukkan tidak terdapat perbedaan secara statistik pada seluruh matriks, namun air dan tanah pertanian menunjukkan konsentrasi tertinggi dibandingkan pemukiman petani dan rumah tangga. Konsentrasi kadmium pada seluruh sampel jauh di bawah nilai batas. Penelitian ini secara jelas memperlihatkan bahwa kondisi tempat bekerja menunjukkan level kadmium yang lebih tinggi dibandingkan kondisi tempat tinggal. Penyebab pencemaran ini dapat berasal dari aktivitas di sekitar industri. Oleh karena itu, petani sebaiknya mempertimbangkan pajanan kadmium saat bekerja.

Kata kunci: Konsentrasi kadmium, tanah pertanian, air pertanian

\section{Introduction}

Cadmium is widely spread in the earth's crust. ${ }^{1}$ This metal is usually found in zinc ore deposits and common a by-product of zinc mining. It is concerned as an environmental pollutant due to its toxics effect on biological system as well as on many organs and with a slow elimination rate. Its half life in human ranged between $10-30$ years. The kidney is considered the critical target organ of chronic effect to cadmium. ${ }^{2-4}$ The well-known situation occurred at the village along Jinzu River in Toyama, Japan. Due to Kamioka Mine as operated by a company, cadmium contamination was found in water causing ItaiItai disease. The symptoms of sufferers were bone decay, renal destruction, back and waist pain, anorexia and

Correspondence: Sara Arphorn, Department of Occupational Health and Safety, Faculty of Public Health, Mahidol University, Bangkok,10400 Thailand, Phone: 66 (02) 644-4069-70-102, e-mail: sara.arp@mahidol.ac.th 
weakness. Furthermore, it was reported that cadmium concentration around the river was at $4.85 \mathrm{mg} / \mathrm{kg}$ soil. ${ }^{5-}$ 8

Mae Sod District is located in Tak Province of the Northern Thailand where zinc mining capacity up to 214,023 metric tons takes place. Mining and milling operation together with grinding, concentrating ores and disposal of tailings, along with mine and mill waste water were performed here. The mining process may cause cadmium contamination to the environment, material transfer and removal of mine tailing. ${ }^{9}$ The agriculture area received irrigation from two creeks (Mae Tao, Mae $\mathrm{Ku}$ ) passing through a zinc mining. ${ }^{2}$ The report of The International Water Management Institute (IWMI) showed the cadmium levels in soil coming from Ban Pae De at Mae Sod. The concentration was ranged from 3.4 to $284.0 \mathrm{mg} / \mathrm{kg}$ in 154 samples or 94 times higher than those of European Economic Community Maximum Permissible (MP) level in soil $(3.0 \mathrm{mg} / \mathrm{kg})$. In the later year, they expanded the sampling sites along Mae Tao creek in Mae Tao Subdistrict. The result was ranged from $0.46-218.00 \mathrm{mg} / \mathrm{kg}$ or about 72 times higher than level of European Economic Community Maximum Permissible (MP) in soil. ${ }^{6,10-11}$ As mentioned above, this area had showed extremely high cadmium levels in the environment that could cause cadmium contamination in rice. This study needs to compare the concentration of farmland soil and water and its concentration at farmer's house which might lead to occupational approach.
Therefore, this study focused on the cadmium concentration in soil and water in farmland and at the residence of farmers and households in Phrathatphadaeng Subdistrict, Mae Sod District, Tak Province, Thailand.

\section{Method}

Phrathatphadaeng Subdistrict is located in Mae Sod District, Tak Province in the Northern Thailand, in the mountain area of the border between Thailand and Myanmar. The zinc mining is located in this area and has been affected by the impacts of cadmium. The sample sites were shown in Figure 1, Mae Tao Mai and Pae De Village are located in the downstream of zinc mining and contaminated areas.

Data sampling was collected during February $6^{\text {th }}-$ $10^{\text {th }}, 2012$. As many as 48 samples of farmers' residence soil and water, 12 samples of households, six samples of farmland soil and eight samples of farmland water. The samples were selected by systematic random sampling. GraphiteFurnace Atomic Absorption Spectrophotometer (GFAAS) model Varian SpectrAA Zeeman 220 was used to analyze cadmium concentration in soil and water.

Soil samples were collected following the Sampling Technique and Strategies and Minnesota Department of Agriculture. ${ }^{12}$ Water samples were collected following USEPA Region 9 Laboratory Richmond California Field Sampling Guidance Document \#1225 Surface Water Sampling. ${ }^{13}$ Samples were prepared and analyzed by the
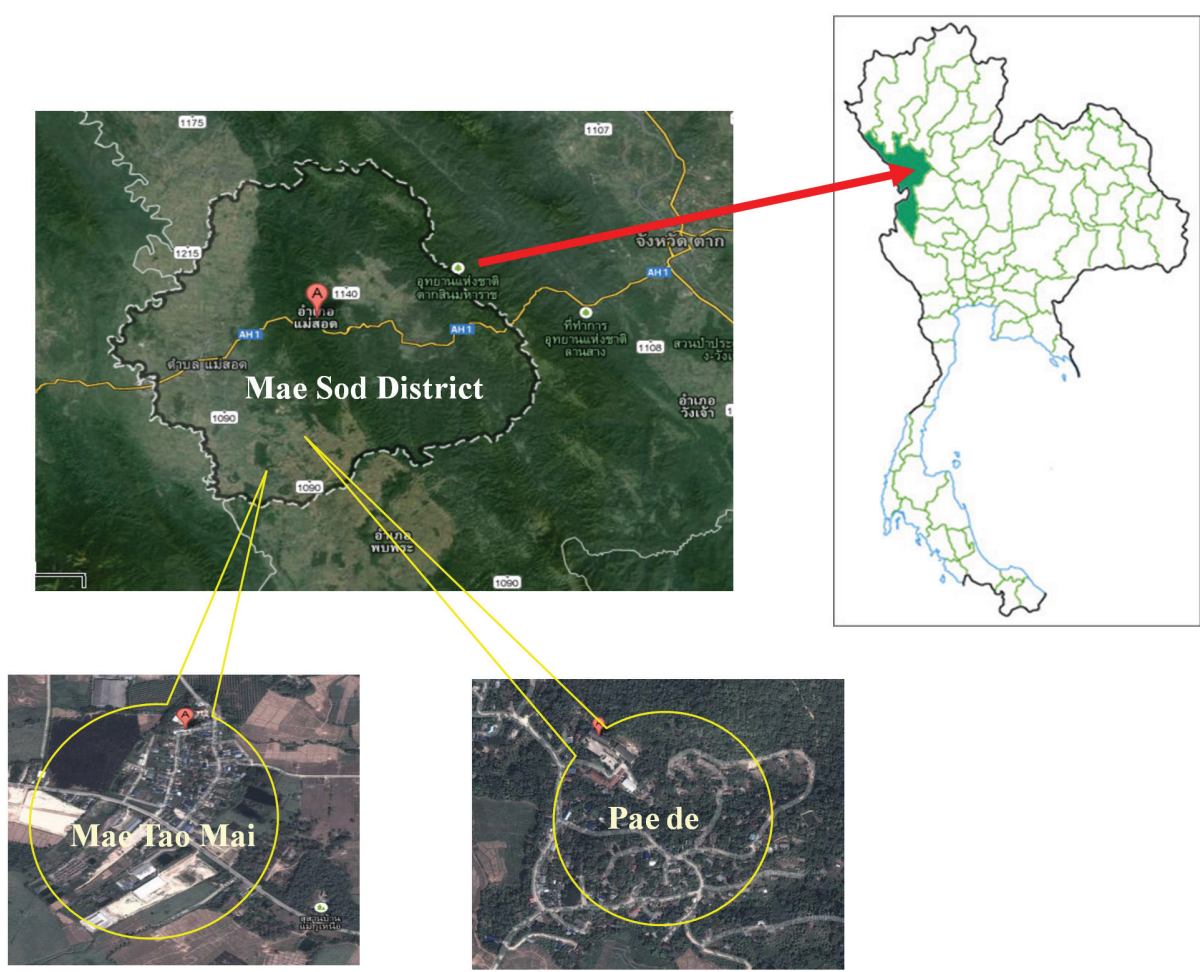

Figure 1. The Overview of Study Area 
GFAAS model Varian SpectrAA Zeeman 220 following the Canadian Society of Soil Science Method with a modification by Center of Excellence on Environmental Health, Toxicology and Management of Chemicals (ETM). ${ }^{14}$

For soil preparation, first, $10 \mathrm{~mL}$ of nitric acid $\left(\mathrm{HNO}_{3}\right)$ was used for matrix digestion. Second, soil samples were dried, milled and filtered before extraction process. Third, the sample was weighed for 0.5 gram and added with $\mathrm{HNO}_{3}$ for $10 \mathrm{~mL}$ into vessel, and assembled the vessels into microwave process for the digestion for 30 minutes. Fourth, after the heating at $210{ }^{\circ} \mathrm{C}$ and 190 psi then vessels were taken out after cooling down process to $50-60{ }^{\circ} \mathrm{C}$. Fifth, came to filter step using filter paper. Next, adjust the volume to $50 \mathrm{~mL}$ by adding distilled water. All of samples were analyzed by GFAAS.

For water preparation, the first was the chemical reagent, $5 \mathrm{~mL}$ of $\mathrm{HNO}_{3}$ was used for the matrix digestion. Second, the sample was added $45 \mathrm{~mL}$ into vessel and added $\mathrm{HNO}_{3} 5 \mathrm{~mL}$ into vessel, and assembled the vessels into microwave step to digest for 30 minutes. Fourth, after the heating at $170{ }^{\circ} \mathrm{C}$ and 190 psi then vessels were taken out, further came to cooling down to 50 $-60{ }^{\circ} \mathrm{C}$. The fifth step was filter using filter paper. Next, adjust the volume to $50 \mathrm{~mL}$ by adding distilled water. All of samples were analyzed by GFAAS.

For sample analysis, chemical reagents were 65\% $\mathrm{HNO}_{3}$ and hydrochloric acid $(\mathrm{HCl})$. Next, standard solution was prepared from $100 \mathrm{ppb}$ cadmium standard solution, then took $1 \mathrm{~mL}$ diluted with $100 \mathrm{~mL}$ deionized water and prepared 5 degree for calibration curve $(0$, $0.2,0.4,0.6,0.8$ and $1 \mu \mathrm{g} / \mathrm{l})$. The samples would be analyzed for cadmium concentration and it should be pre- pared prior to the analysis. The dilution factor was 10 : $0.1 \mathrm{~mL}$ of sample mixed with $0.9 \mathrm{~mL}$ of the deionized water.

The study protocols were approved by the "Ethics Committee for Human Research Faculty of Public health”, Mahidol University, Bangkok with COA No. MUPH 2011-037.

This analysis was performed using SPSS software versions 18 for the descriptive and inferential data analysis. Descriptive statistics were used to describe the cadmium concentration in resident soil and water, farmland soil and water. The cadmium concentration in soil and water did not show in mean value because the value of the cadmium concentration did not show normal distributions. Then the median and interquartile range (IQR) were used to explain the cadmium concentration in soil and water. Inferential statistics was the Mann-Whitney U test for comparing the difference of cadmium concentration between farmland soil and resident soil as well as farmland water and resident water.

\section{Results}

The results of cadmium contamination in living environment among farmers and households consisted of farmland soil, resident soil, farmland water and resident water were presented in Table 1 and Table 2 . The values were all in the range of normal concentration.

\section{Discussion}

Human can absorb cadmium into the body either by ingestion, inhalation and dermal exposure. Factors influencing cadmium absorption are the forms in which cadmium in the food, tobacco and the hygiene behavior.

Table 1. Cadmium Concentration in Samples

\begin{tabular}{|c|c|c|c|c|c|c|}
\hline \multirow{2}{*}{ Sample } & \multirow{2}{*}{ Standard ${ }^{\mathrm{a}}$} & \multicolumn{4}{|c|}{ Cadmium Concentration } & \multirow{2}{*}{ p value } \\
\hline & & Mini-Max & Median & SD & $\mathbf{I Q R}^{\mathbf{b}}$ & \\
\hline \multicolumn{7}{|l|}{ Farmers $(n=48)$} \\
\hline Resident soil (mg/kg) & $37 \mathrm{mg} / \mathrm{kg}$ & $0.00002-0.69$ & 0.018 & 0.142 & 0.078 & 0.225 \\
\hline Farmland soil (mg/kg) & $37 \mathrm{mg} / \mathrm{kg}$ & $0.05-0.61$ & 0.152 & 0.199 & 0.230 & \\
\hline Resident water (mg/l) & $0.005 \mathrm{mg} / \mathrm{l}$ & $0.000006-0.0008$ & 0.00015 & 0.00012 & 0.00013 & 0.345 \\
\hline Farmland water (mg/l) & $0.005 \mathrm{mg} / \mathrm{l}$ & 0.0003-0.0005 & 0.00033 & 0.00007 & 0.00014 & \\
\hline
\end{tabular}

Table 2. Comparison of Cadmium Concentration in Resident Soil and Resident Water among Households

\begin{tabular}{lcllll}
\hline \multirow{2}{*}{ Farmer-related Samples } & Standard Value & \multicolumn{3}{c}{ Cadmium concentration } \\
\cline { 3 - 6 } & & Min-Max & Median & SD & \multirow{2}{*}{ IQR $^{\mathbf{b}}$} \\
\hline Resident soil $(\mathrm{mg} / \mathrm{kg})$ & $37 \mathrm{mg} / \mathrm{kg}$ & $0.0004-0.38$ & 0.021 & 0.106 & 0.086 \\
Resident water $(\mathrm{mg} / \mathrm{l})$ & $0.005 \mathrm{mg} / \mathrm{l}$ & $0.000006-0.0003$ & 0.00014 & 0.00011 & 0.0002
\end{tabular}

asoil from National Environment Board (NEB) 200415, Water from National Environment Board (NEB) 199416,

bInterquartile Range 
Acute effects by ingestion may lead to gastrointestinal disorders, such as nausea, vomiting, abdominal cramps and diarrhea. Acute effects by inhalation may lead to respiratory manifestations, such as severe bronchial and pulmonary irritation, subacute pneumonitis and lung emphysema. Chronic effects occur mainly on the kidneys, lungs and bones. The kidney is the target organ for the general population as well as for occupationally exposed populations. Cadmium is known to accumulate in the human kidney for a long time, from 20 to 30 years, also known to occur health effects on the respiratory system and has been associated with bone disease. ${ }^{15,16}$

The soil cadmium concentration in farmland and residence of farmers and households were lower than the limit values of National Environment Board (NEB), Thailand at $37 \mathrm{mg} / \mathrm{kg} .{ }^{17}$ The median of soil cadmium concentration in households' resident soil, farmers' resident soil, farmland soil were $0.021,0.018$ and 0.152 $\mathrm{mg} / \mathrm{kg}$ respectively. This result was different with the survey of the International Water Management Institute (IWMI) with the Thailand Department of Agriculture that soil cadmium concentrations in two phases from 1998 to 2003 were higher than limit values of NEB at 284 and $218 \mathrm{mg} / \mathrm{kg}$ respectively. The result was different from this study. In IWMI's study, the sampling area is located nearby the mining area. Cadmium compound was mainly related with zinc ores. 5,11 However, the cadmium concentrations in soil of IWMI were higher than those found in this study. It might be from the difference in the sampling collection period in this study. The flooding might cause the reduction of soil cadmium concentration. However, it was agreed with the study of Weeraprapan $\mathrm{P}, 18$ as it was shown that cadmium concentration in sediment of downstream area $(0.84$ and $2.47 \mathrm{mg} / \mathrm{kg}$ ) were higher than those of upstream area (5.32 and $7.86 \mathrm{mg} / \mathrm{kg}$ ). The result was agreed with this finding. The sampling period was similarly collected on February 2012.

The water cadmium concentration in farmland and resident were lower than the limit values of NEB, Thailand at $0.005 \mathrm{mg} / \mathrm{l} .{ }^{19}$ It was agreed with the study of Krissanakriangkrai, et al, ${ }^{20}$ showing that the rainy season demonstrated highest water cadmium concentration, but the level found was lower than the limit values of NEB at $5 \mu \mathrm{g} / \mathrm{l}$. This might be due to the increase in storm water and industrial runoff occurring in this period of time. However, it was different from the study of Akkajit. ${ }^{21}$ It showed that water cadmium concentrations in rainy season $(0.028-0.032 \mathrm{mg} / \mathrm{l})$ were higher than in dry season $(0.005-0.006 \mathrm{mg} / \mathrm{l})$ because the surface water in Mae Tao creek might pass through the $\mathrm{Zn}$ mining area and it would be accumulated in sediment. The result demonstrated high level of cadmium concentration in working area namely farmland soil and water.
The comparison of cadmium concentration in farmer's farmland soil and resident soil had no statistically difference and showed farmland soil had higher cadmium concentration than resident soil at $\mathrm{p}$ value $=0.225$. However, the comparison of cadmium concentration in farmer's farmland water and resident water had no statistically difference and showed farmland water had higher cadmium concentration than resident water at $\mathrm{p}$ value $=0.345$. The cadmium concentrations in all samples among farmers and households were far below the limit values.

The limitation of this study was the period of data collection. It could only be conducted on February 2012 because of the availability of staff working in this study area. Moreover, this area just experienced flood from October 2011 to January 2012. Another limitation was the analysis would be performed in queue, therefore, all of samples were stored for almost one month.

\section{Conclusion}

Concentration in farmland soil and water showed highest concentration compared to farmers and households' resident soil and water. The cadmium concentrations in all samples were remarkable far below the limit values. This study clearly showed that the working conditions of farmer demonstrated higher level of cadmium compared to the living conditions. The cause of this contamination might be from the activities of the surrounding industry. Therefore, it would be recommended that farmers should consider for cadmium exposure while working in farm.

\section{Acknowledgement}

The authors would like to thank to all public health officers in Mae Sod District. We also thank to Center of Excellence on Environmental Health and Toxicology (EHT) for support in analysis. We like to thank the organizing committee of International Meeting of Public Health and the Postgraduate Students association of Public Health Universitas Indonesia and Mahidol University for all supports.

\section{References}

1. Anonymous. Heavy Metal [online]. 2012 [cited 2012 October 25]. Available from http://www.rmutphysics.com/ charud/scibook/metalswu/lesson2-31.htm.

2. Songprasert N, Sukaew T, Kusreesakul K, Swaddiwudhipong W, Padungtod C, Bundhamcharoen K. Additional burden if diseases associated with cadmium exposure. A case study of cadmium concentration rice filed in Mae sot district, Tak province, Thailand. International Journal of Environtmental Research and Public Health. 2015; 12 (8): 9199-217.

3. Swaddiwudhipong W, Mahasakpan P, Funkhiew T, Limpatanachote P. Changes in cadmium exposure among persons living in cadmium-con- 
taminated areas in in Northwestern Thailand: A five year follow-up. Journal of Medical Association of Thailand. 2010; 93 (10): 1217-22.

4. Swaddiwudhipong W, Nguntra P, Kaewnate Y, Mahasakpan P, Limpatanachote P, Aunjai T, et al. Human health effects from cadmium exposure: comparison between persons living in cadmium -contaminated and non- contaminated areas in Northwestern Thailand. The Southeast Asian Journal of Tropical Medicine and Public Health. 2015; 46 (1): 133-42.

5. Lutanie E. Cadmium exposure and testing [online]. ALS Environmental; 2010 [cited 2015 Aug 5]. Available from http://www.caslab.com/news/ cadmium-testing.html.

6. Foulkes EC. Cadmium [online]. Berlin Heidelberg: Springer Publisher; 1986 [cited 2015 Dec 5]. Available from: http://link.springer.com/chapter/10.1007\%2F978-3-642-70856-5_3\#page-1.

7. Friberg L, Elinder CG, Kjellstrom T. Cadmium environmental health criteria 134 [online]. Geneva: WHO; 1992 [cited 2015 Dec 5]. Available from: http://www.inchem.org/documents/ehc/ehc/ehc134.htm

8. Unhalekha U, Kositanont C. Distribution of cadmium in soil around zinc mining area. Thai Journal of Toxicology. 2008; 23 (2): 170-4.

9. Hey-Sook L, Hyo-Taek Chon, Manfred Sager. Heavy metal contamination and health risk assessment in the vicinity of the abandoned Songcheon AU-Ag mine in Korea. Journal of Biochemical Exploration. 2008; 96: 223-30.

10. Simons RW, Pongsakul P, Saiyasitpanich D, Klinphoklap S. Elevated levels of cadmium and zinc in paddy soils and elevated levels of cadmium in rice grain downstream of zinc mineralized in Thailand. Environtmental Geochemical Health. 2005; 27 (5-6): 501-11.

11. Faculty of Environmental and Resource Studied, Mahidol University. Project of pollution standards and environmental management in zinc mining industry, Tak provinces, Nakhon Pathom: Office of Environmental Management Department of Primary Industries and Mines Ministry of Industry; 2006.

12. Minnesota, Department of Agriculture. Collection and analysis of soil samples for cadmium: recommended procedures for homeownersrenters residents, incident response unit; June 2006 [cited 2010 Sep 9].
Available from: http://www.epa.gov/region5/sites/cmcheartland/sompls_fs_mda_200606.pdf.

13. United State Environmental Protection Agency (USEPA). Surface water sampling [online]. USEPA Region 9 Laboratory Richmond California Field Sampling Guidance Document 1999 [cited 2012 Oct 9]. Available from: http://www.epa.gov/region6/surface_water_sampling.pdf

14. Faculty of Science, Mahidol University. Center of Excellence on Environmental Health, Toxicology and Management of Chemicals (ETM). Bangkok: Faculty of Science Mahidol University; 2006.

15. Bernard A, Lauwerys R. Effect of cad exposure in humans. In: Foulkes EC, ed. Cadmium. Handbook of experimental pharmacology. Berlin: Springer Verlag 1986.p.1325-77.

16. Friberg L, Elinder CG, Kjellstrom T. Cadmium Environmental health criteria 134. Geneva: WHO; 1992.

17. Ministry of Natural Resources and Environment, Pollution Control Department. National Environmental Board soil standard No.25. Bangkok: Ministry Natural Resources and Environment, Pollution Control Department; 2004.

18. Weeraprapan P, Phalaraksh C, Kawashima M. Water quality monitoring and cadmium contamination in the sediment of Mae Tao Stream, Mae Sot District, Tak Province, Thailand. International Journal of Environmental Science and Development. 2015; 6 (2): 142-6.

19. Ministry of Natural Resources and Environment, Pollution Control Department. National Environmental Board water standard No.8: Bangkok: Ministry of Natural Resources and Environment, Pollution Control Department; 1994.

20. Krissanakriangkrai O, Supanpaiboon W, Juwa S, Chaiwong, Swaddiwudhipong W, Anderson KA. Bioavailable cadmium in water, sediment and fish, in highly contaminated area on the Thai-Myanmay Border. Thammasat International Journal of Science and Technology. 2009; 14: 60-8.

21. Akkajit P. Review of the current situation of cadmium contamination in agricultural field in the Mae Sot District, Tak Province, Northwestern Thailand. Applied Environtmental Research. 2015: 37 (1): 71-82. 